Ireneusz ŁUĆ*

\title{
WOJSKOWE MONETY NERONA. TYPY ADLOCVT COH I DECVRSIO
}

Wśród brązowych monet (sestertii) Nerona (Nero Claudius Caesar Augustus Germanicus - 54-68) ${ }^{1}$ szczególnie interesujące są te z legendą: ADLOCVT $\mathrm{COH} /$ ADLOCVT COH S.C. i DECVRSIO / DECVRSIO S.C. ${ }^{2}$. Oba typy były bite w mennicach w Rzymie i w Lyonie (Lugdunum) w latach ok. 63-673.

$\mathrm{Na}$ awersie tych numizmatów została ukazana głowa cesarza w wieńcu laurowym, która jest zwrócona w prawo lub w lewo w zależności od emisji monet. Legendę na awersie stanowi napis: NERO CLAVD(ius) CAESAR AVG(ustus) GER(MANICVS) P(ontifex) M(aximus) TR(ibunicia) POT(estas) IMP(erator) $\mathrm{P}($ ater) $\mathrm{P}$ (atriae).

Na rewersie sesterca z legendą: ADLOCVT COH / ADLOCVT COH S.C. widać cesarza Nerona z odkrytą głową i ubranego w togę (togatus). Cesarz stoi na podium-trybunie (suggestus) ${ }^{4}$. Jest zwrócony w lewo i ma wzniesioną prawą rękę (dextra elata) w rzymskim geście powitania. $Z$ tyłu stoi przy nim prefekt pretorium (praefectus praetorio) także ubrany w togę i z gołą głową. Trybuna znajduje się blisko zadaszonej konstrukcji wspartej na kolumnach. Jest to zapewne architektoniczny element muru koszar pretoriańskich (castra

* Dr hab. Ireneusz Łuć - adiunkt w Zakładzie Historii Starożytnej w Instytucie Historii na Wydziale Humanistycznym Uniwersytetu Marii Curie-Skłodowskiej w Lublinie; e-mail: ireneusz. luc@poczta.umcs.lublin.pl.

${ }^{1}$ Por. Prosopographia Imperii Romani, saec. 1. 2. 3., pars 1, ed. E. Klebs - H. Dessau - P. von Rohden, Berlin 1897, C 690, 369-371.

${ }^{2}$ Por. ilustracje $\mathrm{nr} 1$ i nr 2.

${ }^{3}$ Por. H. Mattingly, Coins of the Roman Empire in the British Museum, vol. 1: Augustus to Vitellius, London 1923, LXXIX, CLXIV- CLXV, CLXVIII, CLXX, CLXXVI, CLXXVIII, CCXV, nr 122-126, 218-219; nr 142-147, nr 148-153, nr 154-155, 226-229; nr 302-304, 259-260, nr 311318, 262; E.M. Smallwood, Documents Illustrating the Principates of Gaius, Claudius and Nero, Cambridge 1967, 80; H. Mattingly - E.A. Sydenham, The Roman Imperial Coinage, vol. 1, London 1923, 1968 (reprint), nr 61-63, 149, nr 121-126, nr 127-138, nr 139-141, 154-155; C.H.V. Sutherland - R.A.G. Carson, The Roman Imperial Coinage, vol. 1, London 1984, 139-141, 154-157, nr 95-97, nr 103-104, nr 105-108, 159, nr 130-136, 161, nr 163-166, nr 167-173, nr 174-177, 162; nr 371, 173, nr 386-388, 174, nr 395-397, 175, nr 429, 177, nr 436-437, 177, nr 489-492, 180, nr 507508, 180, nr 564-565, 183, nr 577-582, 184; G. Salamone, L'imperatore e l'esercito. Tipi monetali di età romano-imperiale, Falzea-Reggio 2004, 25-26.

${ }^{4}$ Por. Publius Cornelius Tacitus, Historiae I 36, ed. C. Halm, w: Cornelii Taciti Libri qui supersunt, Historias et libros minores continens, tomus posterior, Leipzig 1861, 18. 
praetoria), którego owalny zarys widać w górnym polu monety ${ }^{5}$. W stronę Nerona i towarzyszącego mu prefekta pretorium maszeruje trzech żołnierzy, którzy są ubrani w tuniki, a na ramiona mają narzucone płaszcze (paenula). U ich pasa wiszą miecze. Dwóch z nich niesie „signa”. Całość opisanej sceny, od dołu, zamyka legenda, którą tworzy napis: ADLOCVT COH. Na emisjach z S(enatus) C(onsulto) inicjały rzymskiego senatu widnieją w lewym i prawym polu rewersu i symbolicznie zamykają całość opisanej sceny.

Drugi typ sesterca $z$ legendą DECVRSIO / DECVRSIO S.C. zawiera wyobrażenie Nerona jadącego na koniu. Na rewersie analizowanej monety został uwieczniony cesarz, który, pędząc przed siebie, trzyma w dłoni lancę. Jest z odkrytą głową i ma na sobie pancerz (kirys), a płaszcz, osłaniający plecy, unosi się w powietrzu. Na niektórych egzemplarzach tegoż sesterca - co było charakterystyczne dla danej serii - Neron mógł być ukazany jako jadący w prawo lub w lewo. Przed władcą mógł się znajdować pieszy żołnierz, który niósł sztandar (vexillum). Najliczniejszą grupę egzemplarzy należących do typu DECVRSIO / DECVRSIO S.C. stanową jednak numizmaty z rewersem przedstawiającym Nerona galopującego na koniu w towarzystwie innego jeźdźca, nieco z tyłu dotrzymującego mu kroku i trzymającego w dłoni sztandar (vexillum). Napis DECVRSIO / DECVRSIO S.C. został umieszony poniżej opisanego wyobrażenia. Natomiast inicjały S(enatus) C(onsulto), jeśli występowały w danej emisji monet, były umieszczone na lewym i prawym polu.

1. Treść legend i okoliczności wybicia. Legendę, która widnieje na rewersie sesterca typ ADLOCVT COH, można odczytać jako: ADLOCVT(io) $\mathrm{COH}$ (ortium) lub ADLOCVT(io) COH(ortis). W obu wypadkach będzie chodziło o „przemowę” do „kohort” albo do „kohorty”, a ściślej do żołnierzy, którzy odbywali służbę na ich szczeblu. Już za czasów republiki przemówienia o takim właśnie charakterze wygłaszali rzymscy dowódcy do legionistów, którzy brali udział w zgromadzeniu (contio militum) odbywającym się zwykle na terenie obozu wojskowego ${ }^{6}$. W okresie cesarstwa zwyczaj wygłaszania „przemówień wojskowych” (adlocutiones ad exercitum) był kontynuowany, a samo ,allocutio” oznaczało słowa „otuchy” i ,zachęty”.

\footnotetext{
${ }^{5}$ Por. Sutherland - Carson, The Roman Imperial Coinage, vol. 1, s. 156: ,in the background, pillared building below battlemented crescent-shaped structure (?the praetorian camp)".

${ }^{6}$ Por. Titus Livius, Ab Urbe condita lib. XXXVI 17, ed. G. Weissenborn - M. Müller: Titus Livius, Ab Urbe condita, pars 4: Libri XXXI-XXXVIII, Lipsiae 1900, 261: „,uocatos in contionem milites paucis est adlocutus"; tamże XXXVIII 17.

${ }^{7}$ Por. tamże, Perioch 104, ed. G. Weissenborn - G. Heraeus: Titus Livius, Ab Urbe condita, pars 4, fasc. 1: Libri XL-CXLII, Periochae Librorum XLVI-CXLII, Lipsiae 1914, 236: „[C. Caesar] trepidationem militum propter metum nouorum hostium ortam adlocutione exercitus inhibuit"; Marcus Cornelius Fronto, Ad Verum Imperatorem II 3, ed. and transl. by C.R. Haines: The Correspondence of Marcus Cornelius Fronto, vol. 2, LCL, London 1919, 1988 (reprint), 196: „Plane non contempseris et orationes ad senatum et adlocutiones nostras ad exercitum". Zob. E. Roschach, $A d$ locutio, w: Dictionnaire des Antiquités Grecques et Romains, éd. Ch.V. Daremberg - E. Saglio, t. 1,
} 
Termin „decursio” wywodził się od „decurrere”, tj. od ,jechać” lub „pędzić", np. konno, mając formę rzeczownika może zostać przetłumaczony jako „defilada” czy „uroczysta parada wojskowa”.

Treść legend obu analizowanych wojskowych monet Nerona nie zawiera precyzyjnych wskazówek, jeśli mamy na uwadze czas i okoliczności ich wybicia. W odniesieniu do sesterca typu ADLOCVT COH Harold Mattingly zasugerował, że pojawienie się tej monety można interpretować jako symbol „przyjacielskich relacji” Nerona z żołnierzami kohort pretoriańskich. Sądzi także, że do wybicia tej monety doszło najprawdopodobniej bez jakiejkolwiek ważnej przyczyny. Czas jej powstania mógł się łączyć z podróżą cesarza do Grecji (lato roku 64) ${ }^{9}$.

Lino Rossi, jako pierwszy, zasugerował, że na rewersie sesterca Nerona typu ADLOCVT COH nie zostali uwiecznieni pretorianie ${ }^{10}$. Analizując m.in. stroje (brak pancerzy, rodzaj widniejących płaszczy), uzbrojenie (typ mieczy), charakter znaków sztandarowych, nie mówiąc już o gestach (cesarza i żołnierzy), a także dokonując porównania tych detali z innymi wyobrażeniami idei „adlocutio", utrwalonymi zarówno na brązowych monetach, m.in. Kaliguli (Gaius Iulius Caesar Augustus Germanicus - 37-41) ${ }^{11}$ i Galby (Servius Galba

Paris 1873, 69-70; J.B. Campbell, The Emperor and the Roman Army 31 B.C. - A.D. 235, Oxford 1984, 72; M.C. Bishop, On parade: status, display, and morale in the Roman army, w: Akten der 14. Internationalen Limeskongresses in Bad Deutsch Altenburg/Carnuntum, 14.-21. September 1986, Römische Limes in Österreich Sonderband, Vienna 1990, 21-22, 26; L.M. Kowerski, Sadder than Simonidean Tears: Cornificius and Simonides in Catullus 38, „The Classical World” 101 (2008) fasc. 2, 154, nota 64 .

${ }^{8}$ Por. Gaius Suetonius Tranquillus, De vita Caesarum, Nero 7, ed. M. Ihm, Leipzig 1907, 235: „,indictaque decursione praetorianis scutum sua manu praetulit”; E. Saglio, Decursio, Decursus, w: Dictionnaire des Antiquités Grecques et Romains, éd. Ch.V. Daremberg, E. Saglio, t. 2/1, Paris 1892, 41; Mattingly, Coins of the Roman Empire in the British Museum, vol. 1, CLXXVIII: „"Decurrere» is a technical term for "to manoeuvre», and gives the noun "decursio»"; K.R. Bradley, Suetonius' Life of Nero. An Historical Commentary, Bruxelles 1978, 59.

${ }^{9}$ Por. Mattingly, Coins of the Roman Empire in the British Museum, vol. 1, CLXXVI; Mattingly - Sydenham, The Roman Imperial Coinage, vol. 1, s. 149, nota 4. Zob. M. Durry, Les cohortes prétoriennes, Paris 1938, 197.

${ }^{10}$ Por. L. Rossi, La guardia pretoriana e germanica nella monetazione Giulio-Claudia. Elementi storici ed archeologici per una nuova interpretazione, „Rivista italiana di numismatica e scienze affini" 15 (1967) 15-16 i nn.

${ }^{11}$ Por. Prospographia Imperii Romani, saec. 1. 2. 3., vol. 1, ed. E. Groag - A. Stein, Berlin - Leipzig 1933, 217. Inspiracją dla Nerona była zapewne brązowa moneta Kaliguli (Caius Iulis Caesar) z legendą ADLOCVT COH, która zainicjowała bicie tego typu w mennictwie rzymskim. $\mathrm{Na}$ temat tej monety zobacz m.in. I. Łuć, Pretorianie na monetach cesarza Klaudiusza, „Lubelskie Wiadomości Numizmatyczne" 6 (1997) 21, nota 1; M. Sommer, Der Kaiser spricht. Die adlocutio als Motiv der Kommunikation zwischen Herrscher und Heer von Caligula bis Konstantin, w: Krieg Gesellschaft Institutionen. Beiträge zu einer vergleichenden Kriegsgeschichte, hrsg. B. Meißner - O. Schmitt - M. Sommer, Berlin 2005, 335-337; I. Łuć, The Military Coins of Caligula and Claudius. The Types ADLOCVT. COH., IMPER. RECEPT. and PRAETOR. RECEPT., w: Studia Lesco 
Imperator Caesar Augustus - 68-69) ${ }^{12}$, jak i na zachowanych płaskorzeźbach (Kolumna Trajana), badacz doszedł do wniosku, że ci trzej żołnierze wchodzili w skład germańskiej straży przybocznej cesarzy Rzymu (Germani corporis custodes). Germańscy gwardziści formowali samodzielną pięćsetosobową kohortę (Cohors Germanorum corporis custodes), którą dowodził odrębny dowódca (curator Germanorum). I jeśliby przyjąć, że L. Rossi ma słusznośćc ${ }^{13}$, to istotnie treść napisu z rewersu analizowanej monety oznaczałaby ADLOCVT(io) $\mathrm{COH}$ (ortis), a nie ADLOCVT(io) COH(ortium), tj. ,przemowę” (do żołnierzy) „kohorty” (germańskiej straży przybocznej), a nie do (żołnierzy) „kohort” (pretoriańskich).

Hipoteza L. Rossiego, którą poparł także Heinz Bellen ${ }^{14}$, została jednak podważona przez Michaela Speidla ${ }^{15}$. Przeanalizował on w sposób drobiazgowy wysuwane argumenty potwierdzające jakoby obecność żołnierzy „cohors Germanorum" na rewersie analizowanego sesterca. Odniósł się przy tym m.in. do sugerowanego przez L. Rossiego „totemicznego rogu” (totem horn), widniejącego jakoby za pasem togi Nerona, czy też „celtyckiego miecza”, który miał być trzymany w dłoni nie przez prefekta pretorium, ale przez ich „,wodza"16. Oczywiście indywidualna interpretacja jest zawsze obarczona subiektywnym punktem widzenia. $Z$ kolei podkreślane różnice, jeśli chodzi o szczegóły, nie zawsze znajdują odzwierciedlenie w wyobrażeniach rewersów, które można zobaczyć na każdym z egzemplarzy (tego samego jakby nie

Mrozewicz ab amicis et discipulis dedicata, ed. S. Ruciński - C. Balbuza - Ch. Królczyk, Poznań 2011, 231-234.

${ }^{12}$ Por. Prosopographia Imperii Romani, saec. 1. 2. 3., pars 3, ed. E. Klebs - H. Dessau - P. von Rohden, Berlin Berlin 1898, S 723, 284-286.

${ }^{13}$ Por. Rossi, La guardia pretoriana e germanica nella monetazione Giulio-Claudia, s. 23-24, 27-28 i nn.

${ }^{14}$ Por. H. Bellen, Die Germanische Leibwache der römischen Kaiser des julisch-claudischen Hauses, Wiesbaden 1981, 50-52, 121, nr 1: Sesterz aus der Münzstätte Lugdunum (Dat. 66-68 n. Chr.): „Nero als togatus mit erhobener Rechten auf einem Podium nach links gewandt, hinter ihm ein Offizier (decurio Germanorum) mit sagulum und spatha. Vor dem Kaiser nach rechts drei Soldaten (Germani corporís custodes) mit sagulum und gladius. Die beiden ersten sind bärtig und tragen Feldzeichen, der dritte erhebt die Rechte. Im Hintergrund ein überdachtes Gebäude mit drei Säulen (castra Germanorum?). Im Feld S-C, im Abschnitt ADLOCVT COH”; tamże, s. 122, nr 2: Sesterz aus der Münzstätte Rom (Dat. 64-66 n.Chr.): „Szene wie auf der Prägung aus Lugdunum (nr 1), jedoch mit anderer Gestaltung des Gebäudes im Hintergrund (zwei Säulen) und Andeutung einer Mauer mit Zinnen (castra Germanorum?). Die drei Soldaten (Germani corporis custodes) sind enger gruppiert; der erste scheint einen Helm zu tragen. Im Feld S-C, im Abschnitt ADLOCVT COH".

${ }^{15}$ Por. M.P. Speidel, Germani Corporis Custodes, w: Roman Army Studies, vol. 2, ed. M.P. Speidel, Stuttgart 1992, 110: „The inevitable conclusion, then, is that Nero's adlocutio coin, bearing the same legend as Caligula's, refers to the pretorian cohorts and not to the Germani corporis custodes".

${ }^{16}$ Por. tamże, s. 106: ,a comparison of their togas leaves no doubt that the otherwise undocumented «totem horn» is but the fold of Nero's toga. Similarly, the «long, Celtic sword with a groove along the middle» held by the officer behind the emperor on the dais is no sword at all but the edge of his garment". 
było) sesterców typu ADLOCVT COH cesarza Nerona. Są różnice, jeśli chodzi o detale ikonograficzne, które wyróżniają monety z danej serii. Dlatego, pamiętając o tym, należy mieć na uwadze fakt, że w tym kontekście jeszcze większego znaczenia nabiera ustalenie okoliczności, które mogły mieć wpływ na wybicie omawianego typu sesterca.

Jednak tylko Heinz Bellen, jako jedyny ze wspomnianych autorów, zasugerował, że sprawę genezy tegoż numizmatu powinno się łączyć ze spiskiem Gajusza Kalpurniusza Pizona (kwiecień roku 65) ${ }^{17}$. Niemiecki uczony - szukając historycznego uzasadnienia umieszczenia wyobrażenia żołnierzy cohors Germanorum na rewersie analizowanego sesterca - w sposób niejako intuicyjny próbował połączyć, znaną z relacji Tacyta, sprawę utraty zaufania Nerona do pretorianów, co było następstwem udziału w przygotowaniach spisku wysokich rangą pretoriańskich oficerów (trybuni i centurionowie) z Feniuszem Rufusem (Faenius Rufus), jednym z dwóch prefektów pretorium na czele ${ }^{18}$.

Fakt, że pretorianie dopuścili się zdrady, został niezbicie potwierdzony w czasie trwania śledztwa, nadzorowanego osobiście przez Nerona i Tygellinusa (Ofonius Tigellinus), drugiego ze wspomnianych prefektów pretorium. Dlatego nie bez powodu w dziele Tacyta pojawia się wzmianka o „wojskowej części” czy wręcz „wojskowym sprzysiężeniu” (militaris coniuratio) Pizona. Neron miał posądzać o sprzyjanie spiskowcom pretoriańskich „weteranów”, tj. żołnierzy kohort pretoriańskich o długim stażu służby ${ }^{19}$. Dlatego cesarz, darząc większym zaufaniem Germanów z cohors Germanorum niż samych pretorianów, do akcji szukania i aresztowania zamachowców miał wysyłać mieszane oddziały, w których skład wchodzili żołnierze z obu tych formacji ${ }^{20}$.

${ }^{17}$ Por. Bellen, Die Germanische Leibwache der römischen Kaiser des julisch-claudischen Hauses, s. 51, nota 115, s. 56, 82, 88-89, 94 i 121: „Erstprägung wohl im April 65 n. Chr. (nach der pisonischen Verschwörung)".

${ }^{18}$ Por. Publius Cornelius Tacitus, Annales 15, 49, ed. C. Halm, Leipzig 1898, 341: ,promptissimos Subrium Flavum tribunum praetoriae cohortis et Sulpicium Asprum centurionem extitisse constantia exitus docuit; 50: adscitae sunt super Subrium et Sulpicium, de quibus rettuli, militares manus Gavius Silvanus et Statius Proxumus tribuni cohortium praetoriarum, Maximus Scaurus et Venetus Paulus centuriones. sed summum robur in Faenio Rufo praefecto videbatur"; tamże 53. 56. 58-62 i 66; Lucius Cassius Dio Cocceianus, Historiae Romanae LXII 24, 1-3. Na temat Gajusza Gawiusza Sylwanusa (C(aius) Gavius Silvanus), trybuna XII kohorty pretoriańskiej zobacz I. Łuć, Prozopografia w badaniach nad karierami żolnierzy wojsk rzymskich, w: Dzieje biurokracji na ziemiach polskich, tom 1, red. A. Górak - I. Łuć - D. Magiera, Lublin - Siedlce 2008, 18-22.

${ }^{19}$ Neron, obawiając się ataku ze strony pretoriańskich spiskowców, polecił, aby straż trzymali przy nim ci z pretorianów, którzy mieli status rekrutów lub od niedawna pełnili służbę w cohortes praetoriae. Por. Publius Cornelius Tacitus, Annales 15, 59, ed. Halm, s. 348: „quos Nero tirones aut stipendiis recentes delegerat: nam vetus miles timebatur tamquam favore imbutus"; tamże 65 i 66 : Ceterum militaris quoque conspiratio non ultra fefellit".

${ }^{20}$ Por. tamże 15, 58: „,volitabantque per fora, per domos, rura quoque et proxima municipiorum pedites equitesque, permixti Germanis, quibus fidebat princeps quasi externis"; tamże 59. Zob. Bellen, Die Germanische Leibwache der römischen Kaiser des julisch-claudischen Hauses, s. 103: „Die Verwendung der germanischen Leibwache bei der Verhaftung des an der pisonischen Ver- 
Kiedy, jak relacjonuje Tacyt, doszło do spacyfikowania sprzysiężenia i odbyły się egzekucje skazanych spiskowców, Neron polecił zebrać się żołnierzom na wiecu i rozdzielić wśród nich pieniądze. Każdy szeregowy żołnierz miał wówczas otrzymać po 2 tys. sestercji (500 denarów) oraz przydział darmowego zboża, wydawanego im odtąd co miesiąc ${ }^{21}$. Mimo iż nie zachowała się już o tym żadna bezpośrednia wzmianka, wydaje się wręcz nieprawdopodobne, aby Neron nie wygłosił wówczas przemowy (adlocutio) do żołnierzy, którzy byli zgromadzeni na wiecu. Nie wiadomo, czy mógł się wówczas zwracać do nich osobiście, czy za pośrednictwem stojącego przy nim - a widocznego przecież na rewersie sesterca - wysokiego rangą wojskowego dowódcy ${ }^{22}$.

Już tylko tak pobieżnie nakreślona powyżej historyczna perspektywa kontestująca kategoryczność przynajmniej niektórych uwag Michaela Speid$\mathrm{la}^{23}$ - sugeruje wyraźnie, że mógł istnieć związek między wybiciem sesterca typu ADLOCVT COH cesarza Nerona, a akcją rozbicia spisku Pizona w roku 65. Aktywnymi uczestnikami tych wydarzeń, jak słusznie zauważył Heinz Bellen, byli bowiem zarówno pretorianie, jak i żołnierze z germańskiej straży przybocznej (cohors Germanorum). Kogo zatem uwieczniono na rewersie analizowanego sesterca?

Określenie „manipulares”, którego użył Tacyt, wskazuje jednoznacznie oczywiście przy założeniu, że na monecie został utrwalony wspomniany już wiec żołnierzy (contio militum) - że mogło tu chodzić jednak o pretorianów. Takim terminem określano pełnoprawnych żołnierzy wojsk rzymskich, którzy pełnili służbę na szczeblu manipułów. I być może na rewersie analizowanej monety zostali uwiecznieni pretoriańscy jeźdźcy (equites praetoriani) - brak noszonych przez nich pancerzy i tarcz - którzy formalnie byli przypisani do poszczególnych centurii, łączonych w manipuły w poszczególnych kohortach pretoriańskich. U boku Nerona stał zapewne sam Tygellinus, prefekt pretorium, który był wówczas najbardziej zaufanym doradcą władcy. Co więcej, wypłata nagród pieniężnych, połączona z przemową (adlocutio) do żołnierzy, odbyła

\footnotetext{
schwörung (65 n. Chr.) beteiligten Personenkreises hatte ihren Grund in dem Mißtrauen Neros gegen die Prätorianer".

${ }^{21}$ Por. Publius Cornelius Tacitus, Annales 15, 70-71, ed. ed. Halm, s. 354: „Quibus perpetratis Nero et contione militum habita bina nummum milia viritim manipularibus divisit addiditque sine pretio frumentum”; Gaius Suetonius Tranquillus, De vita Caesarum, Nero 10, ed. Ihm, s. 236: ,item praetorianis cohortibus frumentum menstruum gratuitum". Szerzej na temat pretoriańskiego żołdu (stipendium) i nagród okolicznościowych (donativa) zob. I. Łuć, Oddziały pretorianów w starożytnym Rzymie: rekrutacja, struktura, organizacja, Lublin 2004, 128-135.

${ }^{22}$ Por. Gaius Suetonius Tranquillus, De vita Caesarum, Nero 25, ed. Ihm, s. 246: ,ut conservandae vocis gratia neque milites umquam, nisi abens aut alio verba pronuntiante".

${ }^{23}$ Por. Speidel, Germani Corporis Custodes, vol. 2, s. 110: „As a consequence, any conclusions drawn from the alleged representation of the Germani corporis custodes are invalid, such as the presumed reward of the Germani for their part in the Pisonian conspiracy, their "paramilitary» character, the buildings in their camp, and their «complete» assimilation to the praetorian cohorts. In particular, the title of their unit must now be called into question".
} 
się wewnątrz pretoriańskich koszar, co sugeruje, oprócz podium-trybuny, także uwieczniona na rewersie analizowanego sesterca zadaszona konstrukcja wsparta na kolumnach, ulokowana zapewne przy murze castra praetoria ${ }^{24}$.

Jest mało prawdopodobne, aby zwrotu manipulares używano w sposób oficjalny wobec Germani corporis custodes. Pomijając kwestię statusu osób, które należały do tej jednostki - a w jej skład oprócz peregrini mogli też wchodzić niewolnicy - należy zaznaczyć, że służbę pełnili oni w ramach dekurii (decuriae). Co więcej, germańska straż przyboczna była formacją o charakterze prywatnym, dlatego żołd i nagrody pieniężne były wypłacane germańskim gwardzistom z prywatnych funduszy cesarza. W sprawie nagród dla żołnierzy kohort pretoriańskich, co miało miejsce w tym wypadku, decyzję o ich wysokości i wypłacie - zapewne na wniosek władcy Rzymu - podejmował jednak senat ${ }^{25}$.

Udział kilku wysokich rangą oficerów korpusu pretoriańskiego w przygotowaniach wykrytego spisku Pizona wyraźnie świadczy, że i w szeregach tej formacji była opozycja wobec Nerona. Z punktu widzenia cesarza oraz jego doradców musiał być to niepokojący sygnał. Tym bardziej, że to pretorianie byli odpowiedzialni za ochronę życia i zdrowia władcy państwa rzymskiego, nie mówiąc już o obronie samego Rzymu i Italii ${ }^{26}$. Dlatego wygłoszenie przemowy (adlocutio) połączone z wypłatą nagród pieniężnych było - a tak to można interpretować - swego rodzaju ,nowym otwarciem” w relacjach cesarza z pretorianami. Ikonograficznym zapisem tego wydarzenia był zaś z kolei analizowany sesterc $\mathrm{z}$ hasłem ADLOCVT(io) $\mathrm{COH}$ (ortium), którego emisje co roku były bite praktycznie aż do momentu obalenia Nerona (8 VI 68).

$\mathrm{W}$ odniesieniu do sesterca $\mathrm{z}$ legendą DECVRSIO / DECVRSIO S.C. ${ }^{27}$ nie ma żadnych wątpliwości, że na rewersie tej monety został przedstawiony Neron dosiadający galopującego konia, któremu towarzyszą, w zależności od emisji, pretoriańscy jeźdźcy (equites praetoriani) lub piechurzy (pedites praetoriani). Treść legendy, o czym już wspomniano, można przetłumaczyć jako „defilada” czy też „uroczysta parada wojskowa”.

Harold Mattingly zasugerował, że wybicie sesterca typu DECVRSIO mogło się łączyć z pasją Nerona do jazdy konnej ${ }^{28}$. Jednakże - jak pokazują zachowane wzmianki źródłowe - ostatni władca z dynastii julijsko-klaudyjskiej jako głównodowodzący armii lubił w ogóle uczestniczyć w przeglądach oddziałów i w paradach wojskowych ${ }^{29}$.

\footnotetext{
${ }^{24}$ Por. Mattingly, Coins of the Roman Empire in the British Museum, vol. 1, CLXXVI.

${ }^{25}$ Por. Lucius Cassius Dio Cocceianus, Historiae Romanae LXII 27, 4.

${ }^{26} \mathrm{Na}$ temat zadań żołnierzy kohort pretoriańskich zob. I.A. Łuć, Excubiae principis. Geneza $i$ zadania żolnierzy kohort pretoriańskich $w$ starożytnym Rzymie, Poznań 2010, 72-96.

${ }^{27}$ Por. Sutherland - Carson, The Roman Imperial Coinage, vol. 1, s. 139: „Decursio, with Type 12 (see p. 157) known only for Rome, alludes again to the praetorians".

${ }^{28}$ Por. Mattingly, Coins of the Roman Empire in the British Museum, vol. 1, CLXXVIII, nota 1.

${ }^{29}$ Por. Publius Cornelius Tacitus, Annales 13, 4, ed. Halm, s. 253: „se mandatis exercitibus consulturum"; Gaius Suetonius Tranquillus, De vita Caesarum, Nero 7, ed. Ihm, s. 235: „militi donativum proposuit indictaque decursione praetorianis scutum sua manu praetulit".
} 
$\mathrm{Na}$ decursio mogły się zatem składać manewry wojskowe, które na co dzień wykorzystywano w wojsku rzymskim, aby szkolić żołnierzy ${ }^{30}$. Mogły to być również swoiste przedstawienia, w czasie których żołnierze pozorowali udział w walkach. Owym manewrom zaś z wielką uwagą mogli się przyglądać zgromadzeni mieszkańcy Rzymu i okolicznych miejscowości.

Neron miał ćwiczyć się w kierowaniu końmi. Czynnie uczestnicząc w takich manewrach, jak słusznie zauważył Michaela Speidel, mógł on nie tylko podnieść swoje wojskowe umiejętności, ale w sposób niejako wizualny miał szansę zademonstrować mieszkańcom państwa rzymskiego - oczywiście za pomocą wyobrażeń z rewersu analizowanego sesterca - że to on był prawdziwym dowódcą armii rzymskiej³1.

Głównymi odbiorcami sesterców typu ADLOCVT COH i DECVRSIO byli żołnierze wojsk rzymskich. W ramach żołdu i okolicznościowych nagród pieniężnych owe monety mogły trafiać nie tylko do pretorianów czy żołnierzy cohors Germanorum, ale z czasem i do legionistów, żołnierzy wojsk pomocniczych (auxilia) oraz tych, którzy służyli we flocie. Pieniądz odgrywał kapitalną rolę w komunikacji między cesarzem a milites Romani. To za pośrednictwem określonych typów idei i haseł władca mógł kreować swój własny wizerunek, np. jako wyćwiczonego jeźdźca i sprawnego dowódcy (vide DECVRSIO).

Z kolei nagłaśniając fakt wygłaszania przez cesarza specjalnych przemów do żołnierzy, którzy brali udział w wiecach wojskowych (vide ADLOCVT $\mathrm{COH})$, mógł nie tylko realizować, wymuszone chwilą, cele polityczne, jak choćby przywrócenie poprawnych relacji Nerona z żołnierzami kohort pretoriańskich po rozbiciu spisku Pizona. Emisje monet ukazujących tego typu spotkania zawsze w szerszym kontekście oznaczały „więź” cesarza z podkomendnymi, co pozytywnie musiało być przez nich odbierane. Dlatego stosowanie hasła adlocutio stanie się ponadczasową ideą w relacjach między żołnierzami i cesarzami państwa rzymskiego ${ }^{32}$.

${ }^{30}$ Por. M.P. Speidel, Riding for Caesar: The Roman Emperors' Horse Guard, London 1994, 15: „A decursio could be a true military training maneuver or merely a commemorative pageant, but in either case it was performed in full view of the soldiers and the public. It called for keen horsemanship, deft handling of weapons, and thorough training by the emperor with his guard". Zob. Bishop, On parade, s. 21-30.

${ }^{31}$ Por. Publius Cornelius Tacitus, Annales 13, 3, ed. Halm, s. 252: „, caelare pingere, cantus aut regimen equorum exercere”. Zob. Speidel, Riding for Caesar, s 15: „The decursio thus not only raised the emperor's skill in the field, it also showed him to the people fulfilling his role: on the parade ground, as on coins, he was manifestly the army's true leader".

${ }^{32}$ Por. Campbell, The Emperor and the Roman Army 31 B.C. - A.D. 235, s. 72: „By these means it will have been possible for emperors to communicate in some way with a reasonably large number of soldiers. This is all the more significant in that the adlocutio was not only a military exhortation to discipline and bravery; the speech to the troops could also be a way of getting the army's support 


\section{NERON'S MILITARY COINS. THE TYPES ADLOCVT COH AND DECVRSIO}

(Summary)

The main recipients of the ADLOCVT COH and DECVRSIO sesterces were Roman soldiers. As part of the pay and occasional cash prizes, these coins were offered not only to the Praetorians or the soldiers of cohors Germanorum, but also to the legionnaires, the soldiers of the Auxilia and those who served in the fleet. Money played a vital role in the communication between the emperor and milites Romani. It was through the use of certain types of ideas and slogans that the ruler created his own image, e.g. as a trained horseman and a competent commander (vide DECVRSIO).

In turn, by publicizing the fact that the emperor gave special speeches to the soldiers who participated in the military rallies (vide ADLOCVT $\mathrm{COH}$ ) he could pursue the political goals that the current situation required, such as the restoration of the correct relations between Nero and the Praetorian soldiers after the failure of the Pisonian conspiracy. Emissions of the coins showing this type of encounter in the wider context always meant the "bond" of the emperor with the subordinates, which was certainly welcomed by them. Therefore, the use of the slogan adlocutio became a universal idea in the relations between the soldiers and the emperors of the Roman state.

Key words: Roman army, military coins, military propaganda, military service, military organization, guards units, guardsmen, cohortes praetoriae.

Słowa kluczowe: armia rzymska, monety wojskowe, propaganda wojskowa, służba wojskowa, organizacja wojskowa, jednostki straży, gwardziści, cohortes praetoriae.

\section{BIBLIOGRAFIA}

\section{Źródła}

Gaius Suetonius Tranquillus, De vita Caesarum libri VIII, ed. M. Ihm, vol. 1, Lipsiae 1907.

Lucius Cassius Dio Cocceianus, Historiae Romanae, ed. and transl. by E. Cary, on basis of the version of H. Baldwin Foster: Cassius Dio's Roman History, vol. 1-9, LCL, London 1914.

Marcus Cornelius Fronto, Epistulae, ed. and transl. by C.R. Haines: The Correspondence of Marcus Cornelius Fronto, vol. 1-2, LCL, London 1919, 1988 (reprint).

for particular items of an emperor's policy, or his general political position. And in time of political crisis the more quickly and effectively the ruler's point of view was impressed on the soldiers and accepted, the less chance there was for a usurper to build up military suport". Zob. I. Łuć, Hadrian's Military Coins. The Types COHORTES PRAETORIAE, EXERCITVS and DISCIPLINA AVGVSTI, w: Hortus Historiae. Księga Pamiatkowa ku czci Profesora Józefa Wolskiego w setnq rocznicę urodzin, red. E. Dąbrowa - M. Dzielska - M. Salamon - S. Sprawski, Kraków 2010, 367-381. 
Publius Cornelius Tacitus, Annales, ed. C. Halm: Cornelii Taciti Libri qui supersunt, $A b$ excessu divi Augusti continens, tomus prior, Leipzig 1898.

Publius Cornelius Tacitus, Historiae, ed. C. Halm, w: Cornelii Taciti Libri qui supersunt, Historias et libros minores continens, tomus posterior, Leipzig 1861, 1-191.

Titus Livius, Ab Urbe condita, ed. G. Weissenborn - M. Müller: Titus Livius, Ab Urbe condita, pars 4: Libri XXXI-XXXVIII, Lipsiae 1900; ed. G. Weissenborn - G. Heraeus: Titus Livius, Ab Urbe condita, pars 4, fasc. 1: Libri XL-CXLII, Periochae Librorum XLVI-CXLII, Lipsiae 1914.

\section{Opracowania}

Bellen H., Die Germanische Leibwache der römischen Kaiser des julisch-claudischen Hauses, Wiesbaden 1981.

Bishop M.C., On parade: status, display, and morale in the Roman army, w: Akten der 14. Internationalen Limeskongresses in Bad Deutsch Altenburg/Carnuntum, 14.-21. September 1986, Römische Limes in Österreich Sonderband, Vienna 1990, 21-30.

Bradley K.R., Suetonius'Life of Nero. An Historical Commentary, Bruxelles 1978.

Campbell J.B., The Emperor and the Roman Army 31 B.C. - A.D. 235, Oxford 1984.

Durry M., Les cohortes prétoriennes, Paris 1938.

Kowerski L.M., Sadder than Simonidean Tears: Cornificius and Simonides in Catullus 38, „The Classical World” 101 (2008) fasc. 2, 139-157.

Łuć I., Pretorianie na monetach cesarza Klaudiusza, „Lubelskie Wiadomości Numizmatyczne" 6 (1997) 21-25.

Łuć I., Oddziały pretorianów w starożytnym Rzymie: rekrutacja, struktura, organizacja, Lublin 2004.

Łuć I., Prozopografia w badaniach nad karierami żolnierzy wojsk rzymskich, w: Dzieje biurokracji na ziemiach polskich, t. 1, red. A. Górak - I. Łuć - D. Magiera, Lublin Siedlce 2008, 13-27.

Łuć I., Hadrian's Military Coins. The Types COHORTES PRAETORIAE, EXERCITVS and DISCIPLINA AVGVSTI, w: Hortus Historiae. Księga Pamiatkowa ku czci Profesora Józefa Wolskiego w setna rocznice urodzin, red. E. Dąbrowa - M. Dzielska - M. Salamon - S. Sprawski, Kraków 2010, 367-384.

Łuć I.A., Excubiae principis. Geneza i zadania żotnierzy kohort pretoriańskich $w$ starożytnym Rzymie, Poznań 2010.

ŁuĆ I., The Military Coins of Caligula and Claudius. The Types ADLOCVT. COH., IMPER. RECEPT. and PRAETOR. RECEPT., w: Studia Lesco Mrozewicz ab amicis et discipulis dedicata, ed. S. Ruciński - C. Balbuza - Ch. Królczyk, Poznań 2011, 231-238.

Mattingly H., Coins of the Roman Empire in the British Museum, vol. 1: Augustus to Vitellius, London 1923.

Mattingly H. - Sydenham E.A., The Roman Imperial Coinage, vol. 1, London 1923, 1968 (reprint).

Prosopographia Imperii Romani, saec. 1. 2. 3., pars 1-3, ed. E. Klebs - H. Dessau - P. von Rohden, Berlin 1897-1898.

Prospographia Imperii Romani, saec. 1. 2. 3., vol. 1, ed. E. Groag - A. Stein, Berlin - Leipzig 1933.

Roschach E., Adlocutio, w: Dictionnaire des Antiquités Grecques et Romains, éd. Ch.V. Daremberg - E. Saglio, t. 1, Paris 1873, 69-70.

Rossi L., La guardia pretoriana e germanica nella monetazione Giulio-Claudia. Elementi storici ed archeologici per una nuova interpretazione, ,Rivista italiana di numismatica e scienze affini” 15 (1967) 15-38. 
Saglio E., Decursio, Decursus w: Dictionnaire des Antiquités Grecques et Romains, éd.

Ch.V. Daremberg - E. Saglio, t. 2/1, Paris 1892, 41.

Salamone G., L'imperatore e l'esercito. Tipi monetali di età romano-imperiale, FalzeaReggio 2004.

Smallwood E.M., Documents Illustrating the Principates of Gaius, Claudius and Nero,

Cambridge 1967

Speidel M.P., Riding for Caesar. The Roman Emperors'Horse Guards, London 1994.

Speidel M.P., Germani Corporis Custodes, w: Roman Army Studies, vol. 2, ed. M.P. Speidel,

Stuttgart 1992, 105-119.

Sommer M., Der Kaiser spricht. Die adlocutio als Motiv der Kommunikation zwischen

Herrscher und Heer von Caligula bis Konstantin, w: Krieg Gesellschaft Institutionen. Beiträge zu einer vergleichenden Kriegsgeschichte, hrsg. von B. Meißner - O. Schmitt - M. Sommer, Berlin 2005, 335-353.

Sutherland C.H.V. - Carson R.A.G., The Roman Imperial Coinage, vol. 1, London 1984.

\section{ANEKS}
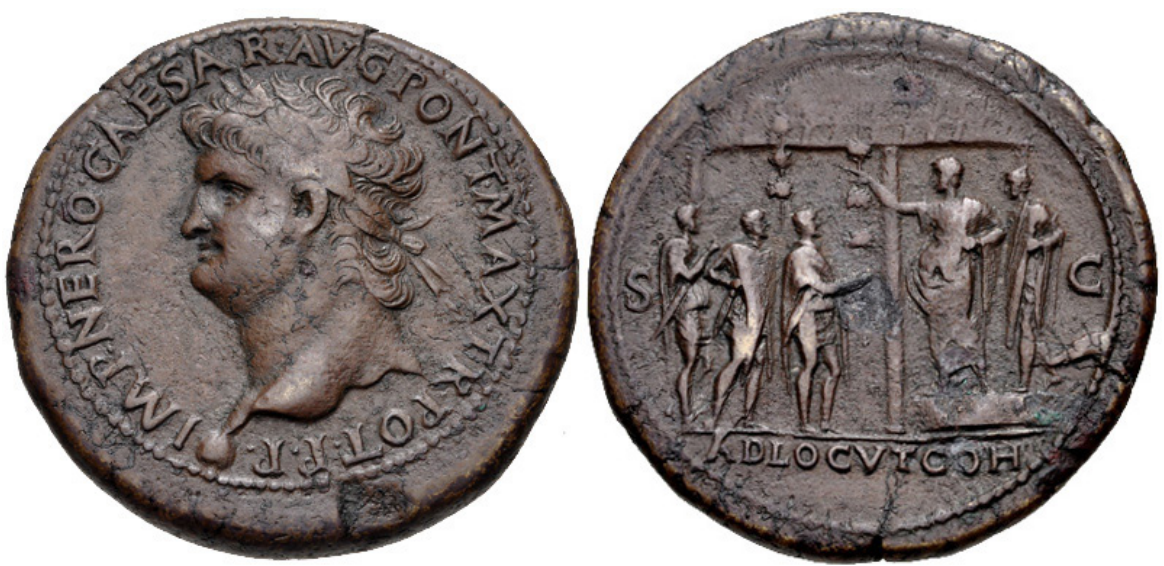

Il. 1: Sesterc Nerona, typ ADLOCVT COH S.C. (awers-rewers ) Lyon/Lugdunum, c. 66 r. po Chr.; H. Mattingly, Coins of the Roman Empire in the British Museum, vol. 1: Augustus to Vitellius, London 1923, nr 304, 260; C.H.V. Sutherland - R.A.G. Carson, The Roman Imperial Coinage, vol. 1, London 1984, nr 491, 180.

Źródło: Wikimedia Commons, the free media repository: https://commons.wikimedia.org/wiki/File:NERONE-RIC_I_491-886135_ADLOCUTIO.jpg; RIC I 491; Lyon 183 (unlisted dies); WCN $\overline{4} \overline{4}$; https://de.wikipedia.org/wiki/Adlocutio\#/media/ File:NERONE-RIC_I_491 886135_ADLOCUTIO.jpg. 

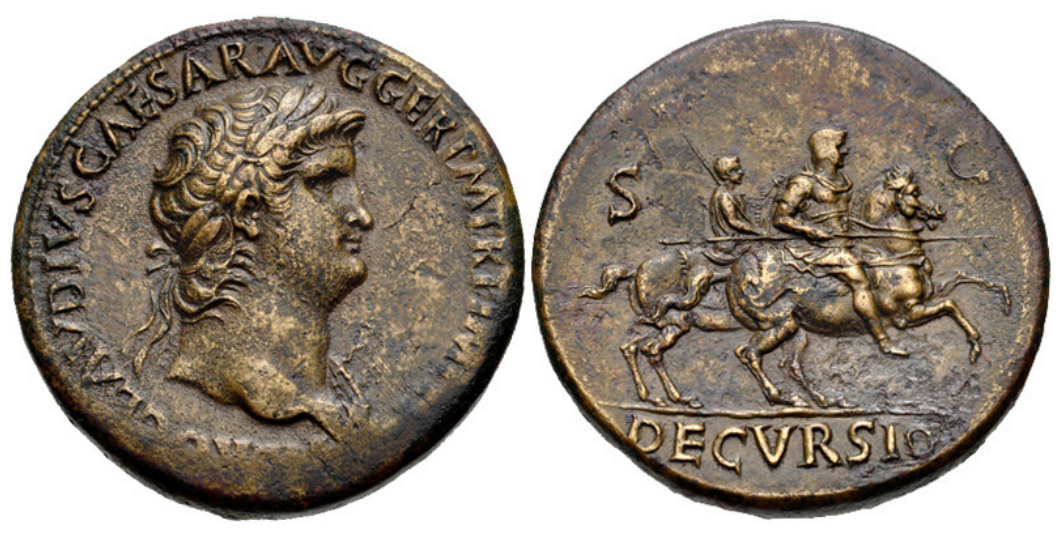

Il. 2: Sesterc Nerona, typ DECVRSIO S.C. (awers-rewers) Lyon/Lugdunum, c. 65 r. po Chr.; C.H.V. Sutherland - R.A.G. Carson, The Roman Imperial Coinage, vol. 1, London 1984, nr 395, 175.

Źródło: Wikimedia Commons, the free media repository: https://commons.wikimedia.org/wiki/File:NERONE-RIC_I_395-907865_DECURSIO.jpg; https://it.wikipedia.org/ wiki/Decursio_equitum. 